\title{
Prediksi Jumlah Kunjungan Wisata Mancanegara Dengan Algoritma Backpropagation
}

\author{
Rini Sovia, Musli Yanto, Putri Melati \\ Fakultas Ilmu Komputer, Program Studi Teknik Informatika, Universitas Putra Indonesia YPTK, Padang, Indonesia \\ Email: ${ }^{1}$ rini_sovia@upiyptk.ac.id, ${ }^{2}$ musli_yanto@upiyptk.ac.id, ${ }^{3}$ putrimelati24061998@gmail.com
}

\begin{abstract}
Abstrak-Kota Bukittinggi adalah kota yang dikenal dengan destinasi wisata yang sangat menarik daya minat wisata mancanegara. Beraneka ragam jenis wisata yang tersaji secara alami dan buatan manusia seperti keindahan gunung, lembah dan keindahan arsiterktur bangunan yang ada yakni Jam Gadang Bukittinggi. Tidak hanya itu, jenis wisata kuliner dan jajanan pasar tradisional juga menjadi daya tarik bagi turis mancanegara untuk berwisata dikota Bukittinggi. Pada penelitian ini, permasalahan yang akan dibahas adalah proses prediksi kunjungan wisata yang dilakukan oleh turis mancanegara ke kota Bukittinggi. Proses prediksi menggunakan konsep metode jaringan saraf tiruan algoritma backpropagation. Data set yang akan dijadikan pembahasan adalah data kunjungan wisatawan mancanegara yang tercatat di Dinas Pariwisata Kota Bukittinggi dari tahun 2018 hingga 2019. Hasil prediksi yang dihasilkan dengan konsep metode jaringan saraf tiruan algoritma backpropagation ini menghasilkan keluaran angka jumlah kunjungan dengan nilai akurasi sebesar 95,64\% dan nilai tingkat kesalahan yang dihasilkan sebesar 4,36\%. Manfaat yang dihasilkan dari penelitian ini adalah membantu pemeritah kota Bukittinggi khususnya Dinas Pariwisata dalam memberikan masukan guna mengelola sektor pariwisata.
\end{abstract}

Kata Kunci: Destinasi, Wisata, Prediksi, Jaringan Saraf Tiruan, Algoritma Backpropagation

\begin{abstract}
Bukittinggi City is known as a tourist destination that is very attractive in foreign tourist interest. Diverse types of tours are presented naturally and man-made the beauty of mountains, valleys and the beauty of the existing architectural buildings is Bukittinggi Clock Tower. Not only that, the type of culinary tourism and traditional market snacks are also an attraction for foreign tourists to travel in the city of Bukittinggi. In this study, the problem that will be discussed is the process of predicting tourist visits conducted by foreign tourists to the city of Bukittinggi. The prediction process uses the concept of artificial neural network backpropagation algorithm. The data set that will be used as a discussion is the data foreign tourist visits recorded in the Tourism Office of Bukittinggi City from 2018 to 2019. The prediction results generated with the concept of artificial neural network backpropagation algorithm produce output numbers of number of visits with an accuracy value of $95,64 \%$ and level value the resulting error is $4,36 \%$. The benefits generated from this research are helping the government of the city of Bukittinggi especially the Tourism Office in providing input to manage the tourism sector.
\end{abstract}

Keywords: Destinations, Travel, Predictions, Artificial Neural Networks, Backpropagation Algorithms

\section{PENDAHULUAN}

Kota Bukittinggi dikenal dengan salah satu kota yang memeiliki daya tarik sangat tinggi dalam sektor pariwisata. Banyak para wisatawan yang melakukan kunjungan wisata ke kota ini untuk mengisi aktifitas liburan mereka. Alasan lainya kota Bukittinggi ini banyak memiliki potensi, yakni kondisi alam yang tersaji dengan begitu indah, udara dilingkungan terasa sangat sejuk, kota ini juga memiliki tempat-tempat peninggalan bersejarah, serta lokasi kota Bukittinggi yang terletak pada posisi strategis sehingga kota ini berpotensi sebagai sebuah kota sebagai kota kunjungan wisata[1]. Hal ini sangat menjadi perhatian bagi pemerintah kota Bukittinggi dalam mengelola aset daerah yang dimiliki. Dalam kebijakan pemerintah kota Bukittinggi, dalam pengembangan sektor pariwisata adapun hal yang akan dilakukan diantaranya 1. Meningkatkan kordinasi hubungan dan sinkronisasi antara pemerintah dengan instansi pelaku industri pariwisata, 2. Meningkatkan kualitas dari proses promosi wisata, 3. Mengembangkan objek destinasi wisata, 4. Meningkatkan akses untuk menuju objek wisata, dan 5. Sosialisasi guna menumbuhkan kesadaran dalam menjaga objek wisata yang ada lingkungan masyarakat sekitar kota Bukittinggi[2].

Mengetahui betapa pentingnya dalam pengelolaan sektor pariwisata yang sangat menjanjikan, maka penelitian ini ditujukan untuk memberikan sebuah hasil yang menjadi masukan bagi pihak yang membutuhkan terutama pemerintah kota Bukittinggi dalam pengelolaan wisata. Tidak hanya wisata lokal yang menjadi target kunjungan destinasi wisata, melainkan wisatawan mancanegara juga menjadi fokus tersendiri dalam hal ini. Dilihat dari riwayat kedatangan wisatawan mancanegara yang melakukan kunjungan wisata ke kota Bukittinggi disepanjang bulan januari hingga bulan april pada tahun 2014, tercatat mencapai 14.864 wisatawan mancanegara yang didominasi dari Asia yakni turis yang berasal dari Malaysia sebesar 72,94\%, selain itu ada juga yang berasal dari Australia, Hongkong, Thailand, Jepang, Cina, Singapura, Prancis, Inggris dan Amerika sekitarnya[3].

Pembahasan yang akan dilakukan dalam penelitian ini adalah prediksi jumlah kunjungan wisatawan mancanegara ke kota Bukittinggi. Sudah banyak para peneliti melakukan penelitian yang membahas kasus prediksi dengan berbagai metode dan algoritma yang digunakan. Pada penelitian ini, proses prediksi akan menggunakan metode jaringan saraf tiruan. Dilihat dari periode waktu, penelitian yang sama sudah dihasilkan, diantaranya menjelaskan bahwa jaringan saraf tiruan merupakan salah satu alternatif dalam melakukan peramalan[4]. Proses prediksi dengan metode jaringan saraf tiruan dalam penelitian ini, menggunakan algoritma backpropagation. Algoritma ini mampu menyelesaikan masalah yang rumit dan berkaitan dengan proses 
penentuan, peramalan, serta pengenalan pola[5]. Realisasi penggunaan algoritma backpropagation dalam penentuan dapat dilihat berdasarkan penelitian yang menjelaskan dalam pengenalan huruf jawa. Penelitia ini Penelitian ini menunjukan hasil pelatihan jaringan yang sangat baik dari beberapa bagian sampel memiliki karakteristik algoritma backpropagation. Hasil keakuratan yang didapat dalam proses penentuan huruf jawa, didapat sebesar $99.563 \%$ untuk data sampel berupa data pelatihan, $61.359 \%$ untuk data sampel diluar data pelatihan, dan $75 \%$ untuk data sampel data pelatihan dan di luar data pelatihan[6]. Algoritma backpropagation dalam pengenalan pola, dapat dilihat berdasarkan penelitian yang sudah dihasilkan menjelaskan bahwa Hasil penelitian pengenalan pola dengan algoritma backpropagation ini dapat berlangsung cukup baik untuk mengidentifikasi gambar wayang kulityang sudah dikenali sebelumnya pada proses training dan testing jaringan[7].

Dalam proses prediksi jumlah kunjungan wisata, algoritama backpropagation sudah digunakan sebelumnya. Berdasarkan penelitian sebelumnya menjelaskan bahwa algoritma ini mampu memperkirakan jumlah kedatangan wisatawan mancanegara ke Provinsi Bali dengan hasil tingkat kesalahan prediksi yang dihasilkan sebesar 70-80\%[8]. Berdasarkan penjelasan sebelumnya, penelitian guna prediksi jumlah kunjungan wisatawan mancanegara ke kota Bukittinggi ini bertujuan untuk melihat laju pertumbuhan wisata yang dilihat dari kedatangan turis mancanegara dan membantu Dinas Pariwisata kota Bukittinggi dalam pengelolaan pariwisata.

\section{METODE PENELITIAN}

Pada penelitian proses prediksi ini, penulis menggunakan metode penelitian dengan model penelitian secara kuantitatif dengan melakukan perhitungan terhadap proses prediksi angka jumlah kunjungan wisata. Proses perhitungan angka yang akan dilakukan sesuai dengan langkah-langkah dari algoritma yang digunakan. Selain metode penelitian secara kuantitatif yang digunakan, penelitian ini juga menyajikan kerangka pikir penelitian yang dapat dilihat pada gambar.1 dibawah ini :

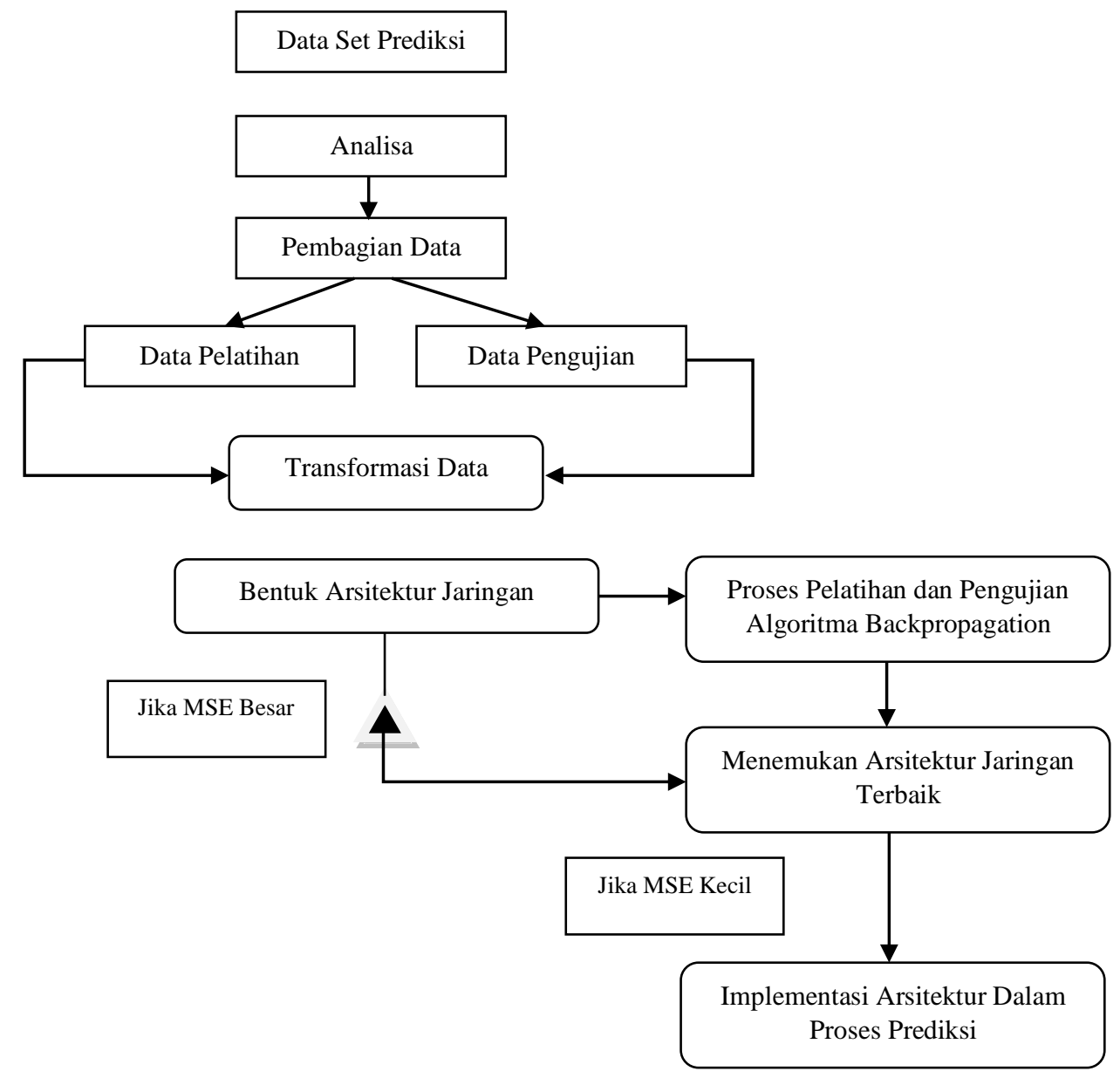

Gambar 1. Kerangka Pikir Penelitian

\subsection{Data Set}

Berdasarkan kerangka pikir penelitian yang tersaji pada gambar.1 menjelaskan bahwa pembahasan dimulai dari proses menemukan data set yang akan digunakan dalam proses prediksi. data set yang dipakai dalam perhitungan 
JURNAL MEDIA INFORMATIKA BUDIDARMA

Volume 4, Nomor 2, April 2020, Page 355-362

ISSN 2614-5278 (media cetak), ISSN 2548-8368 (media online)

Available Online at https://ejurnal.stmik-budidarma.ac.id/index.php/mib DOI 10.30865/mib.v4i2.2048

berasal dari data jumlah kunjungan wisata mancanegara yang tercatat pada Dinas Pariwisata kota Bukittinggi pada tahun 2018 dan 2019. Berikut data jumlah kunjungan wisata mancanegara ke kota Bukittingi dapat dilihat pada tabel.1 dibawah ini :

Tabel 1. Data Kunjungan Wisata Mancanegara Bukittinggi

\begin{tabular}{ccc}
\hline Bulan & Total Kunjungan 2018 & Total Kunjungan 2019 \\
\hline Jan & 1732 & 1602 \\
Feb & 2311 & 2214 \\
Mar & 2103 & 2078 \\
Apr & 1487 & 1782 \\
Mei & 1932 & 1091 \\
Jun & 3145 & 3089 \\
Jul & 2789 & 3011 \\
Agust & 1965 & 2172 \\
Sep & 3014 & 2890 \\
Okt & 3971 & 3471 \\
Nop & 2705 & 2901 \\
Des & 4105 & 4740 \\
\hline
\end{tabular}

Selain data jumlah kunjungan wisata mancanegara yang digunakan sebagai data set dalam penelitian, adapun data lain yang juga akan digunakan sebagai variabel prediktor untuk melakukan proses prediksi. berikut variabel prediktor yang akan digunakan pada penelitian ini dapat dilihat pada tabel.3 dibawah ini :

Tabel 2. Variabel Prediktor Prediksi

\begin{tabular}{cccc}
\hline Total Kunjungan & Inflansi & Kurs & Jumlah Object Wisata \\
\hline 1732 & 3,25 & 13480 & 3 \\
2311 & 3,18 & 13776 & 3 \\
2103 & 3,4 & 13825 & 3 \\
1487 & 3,41 & 13946 & 3 \\
1932 & 3,23 & 14021 & 3 \\
3145 & 3,12 & 14476 & 3 \\
2789 & 3,18 & 14485 & 3 \\
1965 & 3,2 & 14785 & 3 \\
3014 & 2,88 & 15004 & 3 \\
3971 & 3,16 & 15303 & 3 \\
2705 & 3,23 & 14411 & 3 \\
4105 & 3,13 & 14553 & 3 \\
\hline
\end{tabular}

Setelah menemukan variabel prediktor, maka langkah selanjutnya melakukan proses pembentukan pola jaringan yang akan digunakan dalam proses prediksi pada penelitian ini. Adapun X1= Total Kunjungan, X2 = Inflansi, X3 = Kurs Dollar, X4 = Jumlah Wisata, dan $\mathrm{T}=$ Target Prediksi. Berikut pola jaringan dalam melakukan prediksi dapat dilihat pada tabel.3 dibawah ini :

Tabel 3. Pola Jaringan Prediksi

\begin{tabular}{ccccc}
\hline $\mathrm{X} 1$ & $\mathrm{X} 2$ & $\mathrm{X} 3$ & $\mathrm{X} 4$ & $\mathrm{~T}$ \\
\hline 1732 & 3,25 & 13480 & 3 & 1602 \\
2311 & 3,18 & 13776 & 3 & 2214 \\
2103 & 3,4 & 13825 & 3 & 2078 \\
1487 & 3,41 & 13946 & 3 & 1782 \\
1932 & 3,23 & 14021 & 3 & 1091 \\
3145 & 3,12 & 14476 & 3 & 3089 \\
2789 & 3,18 & 14485 & 3 & 3011 \\
1965 & 3,2 & 14785 & 3 & 2172 \\
3014 & 2,88 & 15004 & 3 & 2890 \\
3971 & 3,16 & 15303 & 3 & 3471 \\
2705 & 3,23 & 14411 & 3 & 2901 \\
4105 & 3,13 & 14553 & 3 & 4740 \\
\hline
\end{tabular}


ISSN 2614-5278 (media cetak), ISSN 2548-8368 (media online)

Available Online at https://ejurnal.stmik-budidarma.ac.id/index.php/mib DOI 10.30865/mib.v4i2.2048

\subsection{Data Processing}

Data Processing merupakan proses pengolahan data yang digunakan sebelum proses prediksi dilakukan, langkah yang dilakukan diawali dengan melakukan proses transformasi terhadap data pola jaringan prediksi yang sudah terbentuk. Adapun persamaan transformasi data dapat dilihat pada persamaan 1 dibawah ini :

$$
\mathrm{Y}=\frac{0.8(X-X \min )}{X \max -X \min }+0.1
$$

Setelah proses transformasi terhadap data sudah dilakukan dengan perhitungan menggunakan persamaan 1, maka hasil dari proses transformasi dapat dilihat pada tabel.4 dibawah ini :

Tabel 4. Hasil Tranformasi Data

\begin{tabular}{ccccc}
\hline $\mathrm{X} 1$ & $\mathrm{X} 2$ & $\mathrm{X} 3$ & $\mathrm{X} 4$ & $\mathrm{~T}$ \\
\hline 0.1904 & 0,1000 & 0.8047 & 0.1000 & 0.1836 \\
0,2207 & 0,1000 & 0,8202 & 0,1000 & 0,2156 \\
0,2098 & 0,1000 & 0,8227 & 0,1000 & 0,2085 \\
0,1776 & 0,1000 & 0,8290 & 0,1000 & 0,1930 \\
0,2009 & 0,1000 & 0,8330 & 0,1000 & 0,1569 \\
0,2643 & 0,1000 & 0,8568 & 0,1000 & 0,2614 \\
0,2457 & 0,1000 & 0,8572 & 0,1000 & 0,2573 \\
0,2026 & 0,1000 & 0,8729 & 0,1000 & 0,2134 \\
0,2574 & 0,1000 & 0,8844 & 0,1000 & 0,2510 \\
0,3075 & 0,1000 & 0,9000 & 0,1000 & 0,2813 \\
0,2413 & 0,1000 & 0,8534 & 0,1000 & 0,2515 \\
0,3145 & 0,1000 & 0,8608 & 0,1000 & 0,3477 \\
\hline
\end{tabular}

Hasil data yang telah ditransformasi yang terdapat pada tabel.1, akan dibagi menjadi data pelatihan dan pengujian jaringan yang bertujuan untuk melihat apakah data sesuai dengan metode dan algoritma yang digunakan. Berikut hasil pembagian data dalam tabel.5 dan tabel.6 dibawah ini :

Tabel 5. Tabel Data Pelatihan Jaringan

\begin{tabular}{ccccc}
\hline $\mathrm{X} 1$ & $\mathrm{X} 2$ & $\mathrm{X} 3$ & $\mathrm{X} 4$ & $\mathrm{~T}$ \\
\hline 0.1904 & 0.1000 & 0.8047 & 0.1000 & 0.1836 \\
0,2207 & 0,1000 & 0,8202 & 0,1000 & 0,2156 \\
0,2098 & 0,1000 & 0,8227 & 0,1000 & 0,2085 \\
0,1776 & 0,1000 & 0,8290 & 0,1000 & 0,1930 \\
0,2009 & 0,1000 & 0,8330 & 0,1000 & 0,1569 \\
0,2643 & 0,1000 & 0,8568 & 0,1000 & 0,2614 \\
\hline
\end{tabular}

Tabel 6. Tabel Data Pengujian Jaringan

\begin{tabular}{ccccc}
\hline $\mathrm{X} 1$ & $\mathrm{X} 2$ & $\mathrm{X} 3$ & $\mathrm{X} 4$ & $\mathrm{~T}$ \\
\hline 0.2457 & 0.1000 & 0.8572 & 0.1000 & 0.2573 \\
0,2026 & 0,1000 & 0,8729 & 0,1000 & 0,2134 \\
0,2574 & 0,1000 & 0,8844 & 0,1000 & 0,2510 \\
0,3075 & 0,1000 & 0,9000 & 0,1000 & 0,2813 \\
0,2413 & 0,1000 & 0,8534 & 0,1000 & 0,2515 \\
0,3145 & 0,1000 & 0,8608 & 0,1000 & 0,3477 \\
\hline
\end{tabular}

\subsection{Jaringan Saraf Tiruan dan Algoritma Backpropagation}

Dalam konsep teori, jaringan saraf tiruan memeliki 3 lapisan jaringan yang terbentuk diantaranya lapisan jaringan input, lapisan jaringan tersembuyi dan lapisan jaringan output[9]. Secara defenisi jaringan syaraf tiruan merupakan sebuah proses pengelolaan informasi yang mempunyai sifat dan karakteristik seperti jaringan biologis manusia. Berdasarkan impelementasi yang sudah dihasilkan beberapa penelitian, jaringan saraf tiruan juga merupakan salah satu metode dalam peramalan[10].

Algoritma backpropagation adalah sebuah algoritma yang dapat diterapkan pada jaringan saraf tiruan dengan proses kerja melatih jaringan yang terbentuk. Algoritma ini termasuk dalam supervised learning dimana ciri dari metode ini adalah meminimalkan error pada output yang dihasilkan oleh jaringan. Algoritma backpropagation untuk neural network umumnya diterapkan pada jaringan berlapis banyak (multilayer). Algoritma ini paling tidak mempunyai bagian input, bagian output dan beberapa lapis yang berada di antara input dan output[11]. Jaringan saraf ini dapat ditentukan oleh 3 hal yakni arsitektur jaringan, metode dalam menentukan bobot jaringan dan fungsi aktivasi yang digunakan[12].

Algoritma backpropagation ini memiliki 3 fase diantarnya adalah fase pertama yakni fase maju (propagasi maju) ini dilakukan untuk setiap unit lapisan input jaringan akan dihitung dengan setiap unit lapisan hidden jaringan dengan menggunakan nilai bobot dan bias serta menghitung nilai aktvasi yang akan dikirim pada 
keluaran jaringan atau lapisan output jaringan. Pada fase kedua yakni pelatihan balik (propagasi balik), menerima semua target untuk dibandingkan dengan unit lapisan output yang dihasilkan. Setelah melakukan perbandingan, fase dilanjutkan untuk menghitung total kesalahan dari keluaran jaringan. Fase ketiga adalah fase terakhir yakni fase perubahan bobot, dimana dalam fase ini, merupakan fase menghitung nilai perubahan bobot dan bias yang terjadi berdasarkan hasil perhitungan kesalahan jaringan yang dihasilkan. Ketiga fase ini akan terus menerus berulang sampai mendapatkan nilai kesalahan mendekati nilai kesalahan yang telah dibatasi (Toleransi Error)[12]. Adapun langkah-langkah proses perhitungan algoritma backpropagation sebagai berikut[13]:

Langkah 0 : inisialisasi bobot dengan bilangan acak kecil.

Langkah 1 : jikakondisi penghentian belum terpenuhi, lakukan langkah 2-9

Langkah 2 : untuk setiap pasang pada data pelatihan, lakukan langkah 3-8

Langkah 3 : tiap unit masukan menerima sinyal dan meneruskannya ke unit tersembunyi diatasnya.

Langkah 4 : hitung semua keluaran di unit tersembunyi

Langkah 5 : Pada setiap unit di lapisan tersembunyi $z_{j}$ (dari unit ke-1 sampai unit ke-n ke-p; $i=1, \ldots \ldots, n$; $j=l, \ldots . . p$ ) sinyal output lapisan tersembunyinya dihitung dengan menerapkan fungsi aktivasi terhadap penjumlahan sinyal-sinyal input berbobot $x_{i}$ pada persamaan.2:

$$
Z_{j}=f\left(V o_{j}+\sum X_{I} V_{i j}\right)_{i=1}^{n}
$$

Langkah 6 : Setiap unit di lapisan outputy $_{k}$ (dari unit ke-1 sampai unit ke-m; i=1,...n; k=1,....m) dihitung sinyal output-nya dengan menerapkan fungsi aktivasi terhadap penjumlahan sinyal-sinyal input berbobot $Z_{j}$ bagi lapisan ini pada persamaan.3 :

$$
Y=f\left(W_{o k}+\sum Z_{j} W_{f k}\right)_{i=1}^{p}
$$

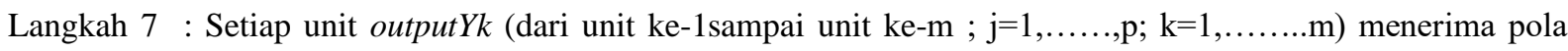
target $t k$ lalu informasi kesalahan lapisan output $(\delta)$ dihitung $\delta_{\mathrm{k}}$ dikirim ke lapisan dibawahnya dan digunakan untuk menghitung besar koreks bobot dan bias $\left(\Delta \mathrm{w}_{\mathrm{jk}}\right.$ dan $\left.\Delta \mathrm{w}_{\mathrm{ok}}\right)$ antara lapisan tersembunyi dengan lapisan output pada persamaan.4:

$$
\begin{gathered}
\delta_{K}=\left(\mathrm{t}_{\mathrm{k}}-\mathrm{y}_{\mathrm{k}}\right) \mathrm{f}^{\prime} \\
\Delta W_{j k}=\alpha \delta_{k} Z_{j} \\
\Delta W_{O k}=\alpha \delta_{k}
\end{gathered}
$$

Langkah 8 : Pada setiap unit di lapisan tersembunyi (dari unit ke-1 sampai unit ke- $p ; i=1, \ldots ., n ; j=1 \ldots . . p$; $k=1 \ldots . \mathrm{m})$ dilakukan perhitungan informasi kesalahan lapisan tersembunyi $\left(\delta_{j}\right) . \delta_{j}$ kemudian digunakan untuk menghitung besar koreksi bobot dan bias $\left(\Delta \mathrm{V}_{\mathrm{ij}}\right.$ dan $\left.\Delta \mathrm{V}_{\mathrm{oj}}\right)$ antara lapisan input dan lapisan tersembunyi pada persamaan.5:

Tahap Perubahan bobot dan bias

$$
\begin{gathered}
\delta j=\left(\sum \delta k W j k\right)_{k=1}^{m} f^{\prime}\left(V_{o j}+\sum X_{i} V_{i j}\right)_{i=1}^{n} \\
\Delta V_{i j}=\alpha \delta_{j} X_{i} \\
\Delta V_{0 j}=\alpha \delta_{j}
\end{gathered}
$$

Tahap 9 : Pada setiap unit outputYk (dari unit ke-1 sampai unit ke-m) dilakukan perubahan bias dan bobot $(j=0, \ldots, p ; k=1, \ldots, m)$ sehingga bias dan bobot yang baru menjadi pada persamaan.6 :

$$
W_{j k}(\text { baru })=W_{j k}(l a m a)+\Delta V i j
$$

dari unit ke-1 sampai unit ke-p di lapisan tersembunyi juga dilakukan perubahan pada bias dan bobotnya $(i=0, \ldots, n ; j=1, \ldots, p)$ pada persamaan.7:

$$
V_{j k}(\text { baru })=W_{j k}(l a m a)+\Delta V i j
$$

Langkah 10 : Tes kondisi berhenti

\section{HASIL DAN PEMBAHASAN}

\subsection{Arsitektur Pola Jaringan}

Pada pembahasan proses prediksi pada penelitian ini, pembahasan diawali dengan membentuk arsiterktur pola jaringan berdasarkan variabel prediktor. Arsirektur jaringan ini akan menjadi gambaran jarigan sarag tiruan 
JURNAL MEDIA INFORMATIKA BUDIDARMA

Volume 4, Nomor 2, April 2020, Page 355-362

ISSN 2614-5278 (media cetak), ISSN 2548-8368 (media online)

Available Online at https://ejurnal.stmik-budidarma.ac.id/index.php/mib

DOI 10.30865/mib.v4i2.2048

dalam proses prediksi jumlah kunjungan wiasata mancanegara ke kota Bukittinggi. Berikut gambar arsitektur jaringan dapat dilihat pada gambar.2 dibawah ini:

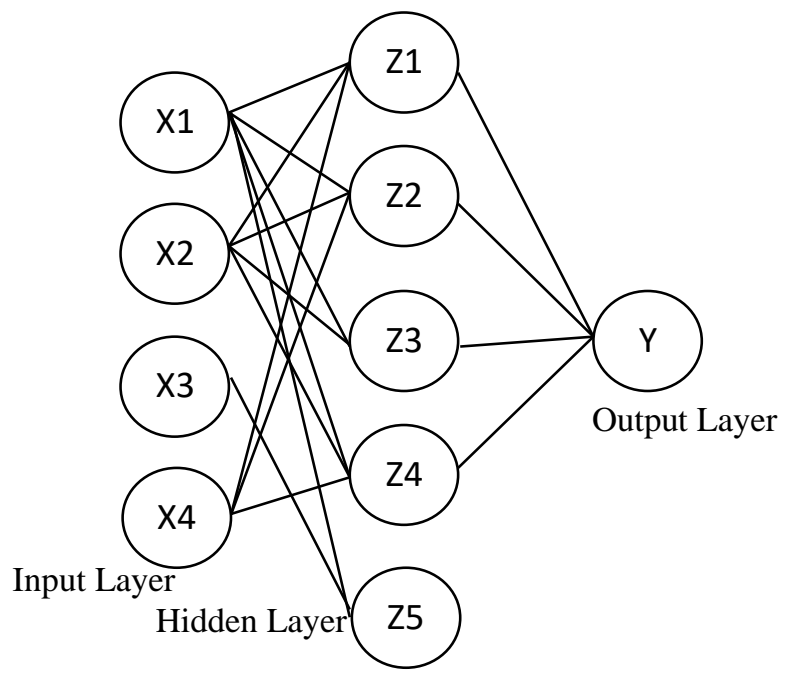

Gambar 2. Arsitektur Pola Jaringan

\subsection{Pelatihan dan Pengujian Jaringan Algoritma Backpropagation}

Proses pelatihan dan pengujian dengan algoritma backpropagation yang akan dilakukan pada penelitian ini akan dibantu dengan penggunaan alat bantu berupa software matlab 6.1. pada proses ini, langkah langkah kerja dari algoritma akan diimplementasikan kedalam sistem yang bertujuan untuk melakukan perhitungan dengan cepat dan membantu peneliti untuk mengetahui apakah pola yang jaringan yang terbentuk sudah memberikan hasil keluaran yang memiliki tingkat akurasi yang tinggi. Berikut hasil pelatihan yang sudah dilakukan dengan menggunakan software matlab 6.1 dapat dilihat pada tabel 7 dan tabel 8 dibawah ini :

Tabel 7. Hasil Pelatihan Jaringan

\begin{tabular}{ccccc}
\hline $\mathrm{T}$ & $\mathrm{Y}$ & Error & Performance & MSE \\
\hline 0.1836 & -1.2668 & 1.4504 & 1.0278 & -0.5769 \\
0,2156 & -0.3773 & 0.5929 & 12.5136 & 0.3223 \\
0,2085 & -0.2578 & 0.4663 & 1.2297 & 4.8327 \\
0,1930 & 0.8207 & -0.6277 & 24.9286 & 0.2865 \\
0,1569 & -0.2174 & 0.3743 & 45.9062 & -6.3996 \\
0,2614 & -1.1555 & 1.4169 & 8.1314 & 0.8168 \\
\hline
\end{tabular}

Tabel 7. Hasil Pengujian Jaringan

\begin{tabular}{ccccc}
\hline $\mathrm{T}$ & $\mathrm{Y}$ & Error & Performance & MSE \\
\hline 0.2573 & 0.2573 & 0.3382 & -0.0809 & 1.8054 \\
0,2134 & 0.2134 & -0.3537 & 0.5671 & 1.4546 \\
0,2510 & 0.2510 & -3.8001 & 4.0511 & 12.6501 \\
0,2813 & 0.2813 & -0.9801 & 1.2614 & 1.7953 \\
0.2515 & 0.2515 & 2.0461 & -1.7946 & 12.4095 \\
0,3477 & 0.3477 & -2.7364 & 3.084 & 4.6616 \\
\hline
\end{tabular}

Berdasarkan hasil dari kedua tabel diatas, berdasarkan nilai MSE yang didapat, maka perlu dibentuk kembali pola jaringan untuk dilatih kembali yang bertujuan menemukan pola jaringan yang terbaik guna prediksi jumlah kunjungan wisata mancanegara ke kota Bukittinggi. Berikut hasil perbandingan pola jaringan yang dibentuk dari beberapa pola dapat dilihat pada tabel 8 dibawah ini :

Tabel 8. Hasil Perbandingan Arsitektur Pola Jaringan

\begin{tabular}{cccccc}
\hline \multirow{2}{*}{ Pola Jaringan } & \multicolumn{2}{c}{ MSE } & \multicolumn{2}{c}{ MAPE } & \multirow{2}{*}{ Akurasi } \\
\cline { 2 - 5 } & Pelatihan & Pengujian & Pelatihan & Pengujian & \\
\hline $4-9-1$ & -0.5769 & -1.0039 & -0.0586 & -0.0443 & 79.835 \\
$4-18-1$ & 2.7679 & 1.0266 & 0.0122 & 0.0433 & 100.9367 \\
$4-27-1$ & 0.3223 & 2.2937 & 0.105 & 0.0194 & 100.9468 \\
$4-36-1$ & 4.8327 & 0.2079 & 0.007 & 0.214 & 99.2325 \\
$4-45-1$ & 0.2865 & -3.3095 & 0.1181 & -0.0134 & 102.2445 \\
$4-54-1$ & -6.3996 & 1.8815 & -0.0052 & 0.0236 & 99.3155 \\
$4-63-1$ & 0.8168 & 0.5266 & 0.0414 & 0.0845 & 97.4335 \\
$4-72-1$ & -3.4082 & 0.5617 & -0.0099 & 0.0792 & 114.5313 \\
$4-81-1$ & -0.2681 & 1.0217 & -0.1262 & 0.0435 & 86.544 \\
& & & & &
\end{tabular}


JURNAL MEDIA INFORMATIKA BUDIDARMA

Volume 4, Nomor 2, April 2020, Page 355-362

ISSN 2614-5278 (media cetak), ISSN 2548-8368 (media online)

Available Online at https://ejurnal.stmik-budidarma.ac.id/index.php/mib

DOI 10.30865/mib.v4i2.2048

\begin{tabular}{cccccc}
\hline \multirow{2}{*}{ Pola Jaringan } & \multicolumn{2}{c}{ MSE } & \multicolumn{2}{c}{ MAPE } & \multirow{2}{*}{ Akurasi } \\
\cline { 2 - 5 } & Pelatihan & Pengujian & Pelatihan & Pengujian & \\
\hline $4-90-1$ & 3.3162 & -2.7058 & 0.0102 & -0.0164 & 100.5505 \\
\hline
\end{tabular}

Berdasarkan perbandingan beberapa pola yang terlihat pada tabel diatas, pola dengan 4-81-1 merupakan pola jaringan yang terbaik untuk melakukan proses prediksi jumlah kunjungan wisata mancanegara. Dari pola tersebut didapat nilai MSE sebesar 0.043561 dan pesetase nilai MAPE sebesar 4,36\% serta tingkat nilai akurasi dari hasil yang akan diberikan sebesar 95,64\%. Pada tahap berikutnya, pembahasan pada penelitian ini akan dilanjutkan kedalam proses prediksi.

\subsection{Proses Prediksi Algoritma Backpropagation}

Proses prediksi yang akan dilakukan pada pembahasan, data yang akan digunakan dapat dilihat pada tabel 9 dibawah ini :

Tabel 9. Tabel Data Prediksi

\begin{tabular}{ccccc}
\hline $\mathrm{X} 1$ & $\mathrm{X} 2$ & $\mathrm{X} 3$ & $\mathrm{X} 5$ & $\mathrm{~T}$ \\
\hline 0,1904 & 0,1000 & 0,8047 & 0,1000 & 0,1836 \\
0,2207 & 0,1000 & 0,8202 & 0,1000 & 0,2156 \\
0,2098 & 0,1000 & 0,8227 & 0,1000 & 0,2085 \\
0,1776 & 0,1000 & 0,8290 & 0,1000 & 0,1930 \\
0,2009 & 0,1000 & 0,8330 & 0,1000 & 0,1569 \\
0,2643 & 0,1000 & 0,8568 & 0,1000 & 0,2614 \\
0,2457 & 0,1000 & 0,8572 & 0,1000 & 0,2573 \\
0,2026 & 0,1000 & 0,8729 & 0,1000 & 0,2134 \\
0,2574 & 0,1000 & 0,8844 & 0,1000 & 0,2510 \\
0,3075 & 0,1000 & 0,9000 & 0,1000 & 0,2813 \\
0,2413 & 0,1000 & 0,8534 & 0,1000 & 0,2515 \\
0,3145 & 0,1000 & 0,8608 & 0,1000 & 0,3477 \\
\hline
\end{tabular}

Data yang terlihat didalam tabel 9, dimana nilai target diambil berdasarkan data kunjungan wisatawan mancanegara pata tahun 2019 yang sudah ditransformasi. Proses yang akan dilakukan pada tahap ini masih menggunakan alat bantu software matlab 6.1 untuk proses prediksi. berikut hasil yang didapat pada tabel 10 dan gambar 3 yang terlihat dibawah ini:

Tabel 10. Hasil Prediksi

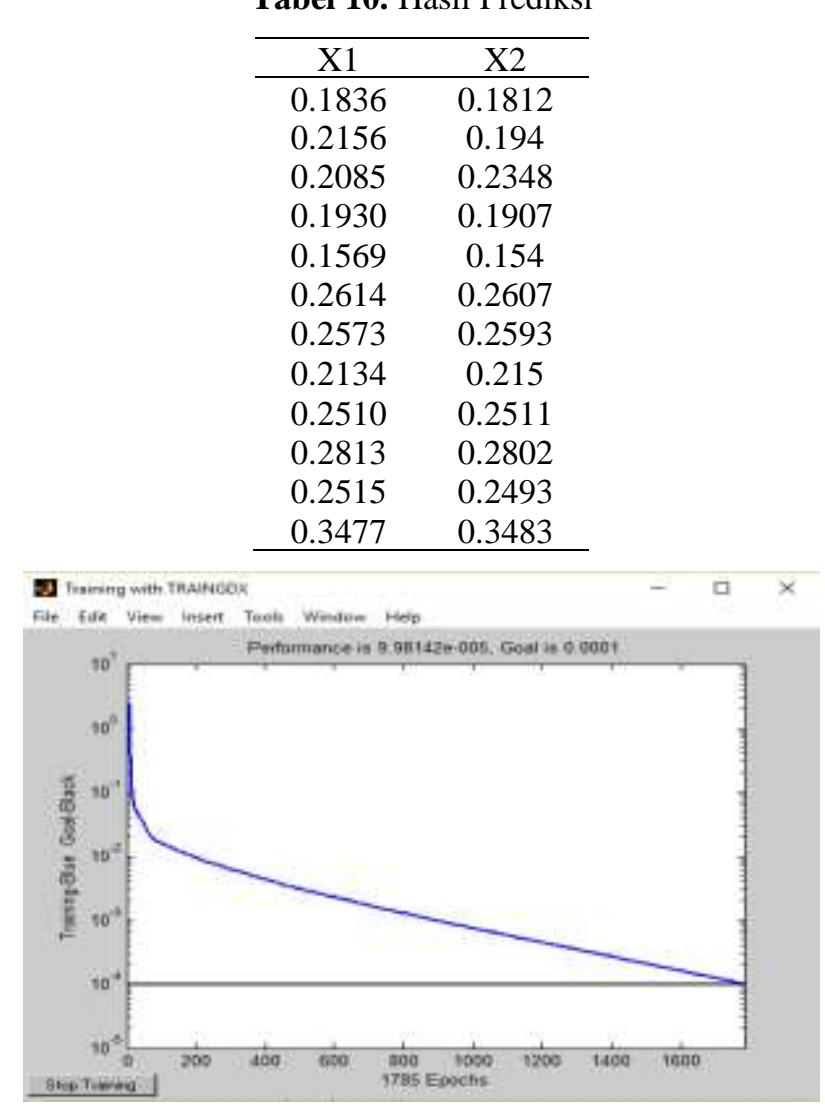

Gambar 3. Hasil Grafik Prediksi 
Proses yang akan dilakukan setelah dilakukan proses prediksi yang dibantu dengan penggunaan software matlab 6.1, maka hasil prediksi yang masih dalam bentuk bilangan berkoma tersebut mesti di denormalisasi kembali guna melihat hasil prediksi kedalam bentuk angka yang sebenarnya. Berikut persamaan 8 yang digunakan dalam proses denormalisasi hasil prediksi:

$$
\text { Denormalisasi }=\mathrm{Y} *(\mathrm{Xmax}-\mathrm{Xmin})+\mathrm{Xmin}
$$

Dari hasil denormalisasi tersebut makan hasil yang didapat mampu memberikan sebuah masukan bagi pemerintah kota Bukittinggi untuk mengelola wisatawan dan juga melihat pertumbuhan grafik peningkatan dan penuruan angka jumlah wisawan mancanegara yang akan terjadi pada periode waktu berikutnya.

\section{KESIMPULAN}

Proses prediksi yang sudah dilakukan dalam melihat jumlah kunjungan wisatawan mancanegara ke kota Bukittingi dengan menggunakan jaringan saraf tiruan algoritma backpropagation memperoleh hasil dengan tingkat kesalahan yang sangat kecil sebesar 4,36\% dan tingkat nilai akurasi hasil yang didapat sebesar 95,64 \% . Hal ini menunjukan bahwa jaringan saraf tiruan mampu melakukan proses prediksi jumlah kunjugan wisatawan mancanegara ke kota Bukittinggi dengan menggunakan variabel prediktor diantaranya : jumlah kunjungan yang terjadi pada periode sebelumnya, angka tingkat inflansi yang terjadi, nilai tukar Rupiah terhadap Dollar (Kurs) dan jumlah objek wisata yang tersaji di kota Bukittiggi tersebut. Hasil prediksi akan digunakan bagi pihak yang berkepentingan dalam pengelolaan pariwisata khususnya meningkatkan jumlah kunjungan wisata bagi turis mancanegara di kota Bukittinggi.

\section{UCAPAN TERIMAKASIH}

Ucapan terima kasih kami sebesar-besarnya kepada Bapak H. Herman Nawas dan Ibu Dr. Hj.Zerni Melmusi, SE, MM, Ak, CA selaku Yayasan Perguruan Tinggi Komputer (YPTK) Padang yang telah membantu dalam penelitian ini. Selanjutnya kepada Bapak Rektor Universitas Putra Indonesia YPTK Padang Prof. Dr. H. Sarjon Devit, S.Kom, M.Sc yang telah memberikan kesempatan untuk waktu dan pengarahan kepada kami selaku peneliti.

\section{REFERENCES}

[1] Arianti, Desi, 2014, Pengaruh Sektor Pariwisata Terhadap Perekonomian dan Keruangan Kota Bukittinggi (Pendekatan Analisis Input Output), Jurnal Wilayah dan Lingkungan, Vol.2 No.3.

[2] Sanesta, Aldian, 2015, Strategi Pengembangan Kepariwisataan di Kota Bukittinggi, Jurnal FISIP Volume 1 No. 2.

[3] Ahyuni dan Mariya, Sri, 2015, minat wisatawan asing berkunjung ke objek wisata di wilayah bagian selatan provinsi sumatera barat, Jurnal Geografi fakultas ilmu sosial Unversitas Negeri Padang, Vol.4, No.2.

[4] Chang-Jui Lin, Hsueh-Fang Chen, Tian-Shyug Lee, 2011, Forecasting Tourism Demand Using Time Series, Artificial Neural Networks and Multivariate Adaptive Regression Splines: Evidence from Taiwan, nternational Journal of Business Administration Vol. 2, No. 2;

[5] Eka Pandu Cynthia1, Edi Ismanto, 2017, Jaringan Syaraf Tiruan Algoritma Backpropagation Dalam Memprediksi Ketersediaan Komoditi Pangan Provinsi Riau eminar Nasional Teknologi Informasi, Komunikasi dan Industri (SNTIKI) 9.

[6] Nazla Nurmila, Aris Sugiharto, Eko Adi Sarwoko,2006, Algoritma Back Propagation Neural Network Untuk Pengenalan Pola Karakter Huruf Jawa, Jurnal Masyarakat Informatika, Vol: 1, No: 1.

[7] Kristian Adi Nugraha, Albertus Joko Santoso, Thomas Suselo, 2013, algoritma backpropagation pada jaringan saraftiruan untuk pengenalan pola wayang kulit, Seminar Nasional Informatika (semnasIF 2013).

[8] Wayan Oger Vihikan, I Ketut Gede Darma Putra, I Putu Arya Dharmaadi, 2017, Foreign Tourist Arrivals Forecasting Using Recurrent Neural Network Backpropagation Through Time, TELKOMNIKA, Vol.15, No.3.

[9] Yue-Gang Songa, Yu-Long Zhou, Ren-Jie Han, 2018, Neural networks for stock price prediction, journal of Difference Equations and Applications.

[10] Jamal, A., Suripto, S., Syahputra, R. (2015). MultiBand Power System Stabilizer Model for Power Flow Optimization in Order to Improve Power System Stability. Journal of Theoretical and Applied Information Technology (JATIT), 80(1), pp. 116-123.

[11] Nabilla Putri Sakinah, Imam Cholissodin, Agus Wahyu Widodo, 2018, Prediksi Jumlah Permintaan Koran Menggunakan Metode Jaringan Syaraf Tiruan Backpropagation, Jurnal Pengembangan Teknologi Informasi dan Ilmu Komputer Vol. 2, No.7.

[12] Rini Sovia, Musli Yanto, Widya Nursanty, 2016, Implementation Of Signature Recognition By Using Backpropagation, UPI YPTK Journal of Computer Science and Information Technology.

[13] J. J. Siang, Jaringan Syaraf Tiruan dan Pemrograman menggunakan MATLAB, Yogyakarta: ANDI, 2005 